e-ISSN: 2776-222X

Vol. 1(1) 2021, pp. 13 - 22

\title{
The effort to enhance pupils cognitive learning achievement using contextual teaching and learning approach
}

\author{
Milburga Bhure, Felix Welu, Siprianus See*, Maria Kristina Ota \\ Universitas Flores, Indonesia
}

\begin{abstract}
Contextual teaching and learning (CTL) become learning that can empower pupils' cognitive learning achievement. The research objective was to enhance pupils' cognitive learning achievement (CLA) using the CTL approach. The classroom action research by Kemmis and McTaggart was used in this research. The subjects of this study were pupils of grade IV SDK Doreng, Doreng District, Sikka Regency. Participant research was ten pupils' (three boys, seven girls). Ten multiple-choice tests were used for the evaluation of each cycle. Analysis of data was quantitatively and percentage-five categories for student CLA. The success indicator is based on a score of 65 and classical completeness of $85 \%$. The results showed that the activity of pupils and teachers in the first cycle was low. This finding was followed by not achieving completeness, where only $70 \%$ of pupils completed. The second cycle findings inform that pupils' and teacher activities were excellent, followed by classical completeness, reaching $100 \%$. This action research concludes that CTL can improve pupils' CLA. This research recommends using CTL in the future to enhance pupils' CLA.
\end{abstract}

Keywords: Contextual learning, student learning outcomes, learning in elementary schools, social studies learning

\section{Upaya meningkatkan prestasi belajar kognitif siswa menggunakan pendekatan pembelajaran kontekstual}

\begin{abstract}
Abstrak: Pembelajaran kontekstual atau dikenal dengan CTL (contextual teaching and learning) menjadi pembelajaran yang dapat memberdayakan pretasi belajar kognitif siswa. Tujuan penelitian adalah untuk meningkatkan prestasi belajar kognitif (PBK) siswa menggunakan pendekatan CTL. Penelitian Tindakan kelas Kemmis dan McTaggart digunakan dalam riset ini. Subjek penelitian ini adalah siswa kelas IV SDK Doreng, Kecamatan Doreng, Kabupaten Sikka. Subjek penelitian adalah sepulun siswa (3 laki-laki, 7 Perempuan). Sepuluh tes pilihan ganda digunakan untuk evaluasi setiap siklus. Data Dianalisis secara kuantitaif dan persentase. Lima kategori untuk ketercapaian PBK siswa. Indikator keberhasilan berdasarkan skor 65 dan ketuntasan klasikal 85\%. Hasil penelitian menunjukkan bahwa aktivitas siswa dan guru siklus pertama adalah rendah. Temuan ini diikuti dengan belum tercapai ketuntasan klasikal, dimana hanya 70\% siswa tuntas. Temuan pada siklus kedua menginformasikan bahwa aktivitas siswa dan guru sangat baik, diikuti ketuntasan klasikal mencapai $100 \%$. Kesimpulan penelitian Tindakan ini adalah CTL dapat meningkatkan PBK siswa. Riset ini merekomendasikan untuk menggunakan CTL di masa depan untuk memperbaiki PBK siswa.
\end{abstract}

Kata Kunci: Pembelajaran kontekstual, Hasil belajar siswa, pembelajaran di SD, pembelajaran IPS

Received: 03-03-2021

Accepted: 17-06-2021
To cite this article: Bhure, M., Welu, F., See, S., \& Ota, M. K. (2021). The effort to enhance pupils cognitive learning achievement using contextual teaching and learning approach. Journal of Research in Instructional, 1(1), 13-22. https://doi.org/10.30862/jri.v1i1.3 


\section{INTRODUCTION}

Education is universal, meaning that it is always present in human life. Without education, humans will not develop. In other words, education determines whether a person is good or bad. Pupils are immature people and have a number of basic potentials that still need to be developed. The potential in question generally consists of three categories, namely cognitive, affective, and psychomotor. Learning achievement is the level of humanity possessed by pupils in accepting, rejecting and assessing the information obtained in the teaching and learning process. A person's learning achievement is in accordance with the level of success of something in studying the subject matter. It is stated in the form of grades or report cards for each field of study after the pupils experience the teaching and learning process.

In order to educate the nation's life, good quality education is needed. Education is the basis for shaping the character and body of children in harmony with nature and society. So that one of the efforts to determine the quality of education is to increase the ability of the quality of teachers. This ability includes mastering the curriculum, learning materials, the ability to use methods and the ability to use the environment as a learning resource. Learning activities entailed by educators and pupils who are interactive and who use an approach to the teaching method in an attempt to engage the pupils in the learning experiences (Abdullah, 2017; Nusantari et al., 2020). Therefore, in teaching and learning activities the teacher must be able to choose various methods and appropriate strategies according to the material he teaches to stimulate pupils to always be active in expressing opinions and always foster good cooperation between pupils to improve the learning achievement expected by the teacher.

However, according to the results of observations on the pupils of grade IV SDK Doreng, it was found that the learning process was not as expected. When the teacher explains the subject matter, the pupils' attention is very less and more silent. Pupils' learning achievement is still low because the involvement of pupils in the teaching and learning process is very less. Three to five out of ten active pupils answered questions from the teacher. In the discussion process, the number of pupils who asked questions was very few. This is a problem, especially in social studies learning. Teachers are not optimal in learning such as using time and responding to pupils (Astuti et al., 2020).

Social Sciences (IPS) is one of the main subjects taught in elementary schools. When examined further, the learning objectives of Social Sciences have a very important role to develop knowledge, skills, and values that enable pupils to become citizens who excel actively in a democratic and responsible society. The low learning achievement of pupils in social studies shows that there is an index of the low learning performance of pupils, pupils' learning motivation, and the ability of teachers to choose learning strategies are not in accordance with the material being taught so that many pupils get social studies scores below 60. After interviews with pupils Many do not understand this because the learning strategies provided by the teacher are not in accordance with the material being taught so that pupils' learning achievement is very low.

Regardless of the learning process, social studies integrated topics can be explored through several different approaches (Abdullah, 2017). In connection with the problems that arise, the alternative chosen to solve them is through a Contextual Teaching and Learning (hereinafter CTL) approach to increase cognitive learning achievement (CLA). CTL 
is an alternative to learning (Widodo, 2020). The choice of this approach has several reasons: 1) learning is more meaningful and real (Prastuti et al., 2020), 2) learning is centered on pupil activity, and 3) getting used to collaboration between pupils (Rodiah, 2020). CTL is learning created by the teacher as closely as possible to real world situations.

The CTL process is oriented towards information acquisition, individualization and social interaction. Information processing implies that pupils manage information, monitor it and develop strategies regarding information. The results of the study (Tutut Rahmawati, 2018) in ten studies prove that CTL is suitable for motivating pupils and optimally improving CLA. CTL can build pupil knowledge (Anggraeni et al., 2017). Pupils is not bored with CTL (Utami, 2021). The CTL approach is able to empower the motivation and critical thinking of pupils (Sarwinda et al., 2020). Face-to-face instruction like CTL, on the other hand, provides pupils with various learning opportunities that are enjoyable and deals that are communicative (Widodo, 2020). In teaching social science, pupils are helped to interpret material concepts through CTL (Susiloningsih, 2016).

Previous research findings revealed that CTL can promote CLA pupils. There is nothing wrong with applying CTL in learning. Difficulties in teaching by teachers on abstract concepts can be handled through the CTL application. Teachers often find it challenging to apply vague and abstract concept learning principles (Hyun et al., 2020). It can be resolved via CTL. Contextual Teaching and Learning as a learning concept that helps teachers relate the material they teach to students' real world situations so that the knowledge possessed will be applied in the surrounding environment (Prastuti et al., 2020). Problems that occur must be reflected and followed up. Otherwise, the problem will get bigger and unsolvable. Reflection is a process of teachers experience and knowledge which is obtained and reordered for future improvement (Firdaus \& Dewi, 2018). The fix that becomes the solution is the use of CTL. CTL is expected to be an alternative to change the problematic class conditions. The research objective was to enhance pupils' cognitive learning achievement (CLA) using the CTL approach.

\section{METHOD}

The type of research used by the author in this study is Classroom Action Research. To facilitate the action, the researcher conducted a Classroom Action Research by referring to the research procedure which will be described in outline below. The reference basis for this research procedure is taken from the details of the research procedure developed by Kemmis \& McTaggart, (1988). In this study, the subjects in this study were the pupils of class IV SDK Doreng, Doreng District, Sikka Regency. There were 10 pupils, consisting of 3 male pupils and 7 female pupils.

The research instrument used by the author is interview guide, observation or observation guide, documentation, from photos or videos. The research instrument consisted of 10 multiple choice tests with four choices for each cycle. This instrument is in accordance with the purpose of data collection in determining the level of creativity of social studies subject teachers in applying the CTL approach to generate learning achievement for fourth grade pupils. Table 1 shows fifteen pupil activities measured in this study. 
Table 1. List of pupils activities

\begin{tabular}{clc}
\hline No & \multicolumn{1}{c}{ Activities } & Code \\
\hline 1 & Ability to think and analyze questions & $\mathrm{A} 1$ \\
\hline 2 & Answer the teacher's questions & $\mathrm{A} 2$ \\
\hline 3 & Answer questions accurately and clearly & $\mathrm{A} 3$ \\
\hline 4 & Ability to defend argument & $\mathrm{A} 4$ \\
\hline 5 & Dare to ask questions & $\mathrm{A} 5$ \\
\hline 6 & Critical in asking questions & $\mathrm{A} 6$ \\
\hline 7 & Able to link between concept and reality & $\mathrm{A} 7$ \\
\hline 8 & Give a concrete example in asking & $\mathrm{A} 8$ \\
\hline 9 & Analytical thinking skills & $\mathrm{A} 9$ \\
\hline 10 & Synthetic thinking skills & $\mathrm{A} 10$ \\
\hline 11 & Able to find a solution to a problem & $\mathrm{A} 11$ \\
\hline 12 & Provide various solutions in solving problems & $\mathrm{A} 12$ \\
\hline 13 & Able to connect between concepts & $\mathrm{A} 13$ \\
\hline 14 & Critical of problems & $\mathrm{A} 14$ \\
\hline 15 & Accept your friend's opinion logically and make sense & $\mathrm{A} 15$ \\
\hline
\end{tabular}

The success indicator was that students are said to be complete if they get a score of 65. Classically complete, namely $85 \%$ of students get a score of 65 . Data from observations about pupil activities will be analyzed using percentages that can describe pupil activities and the ability of classroom management by the teacher during the activity. The data obtained by the test technique is in the form of raw data, which needs to be processed and analyzed to be able to provide answers about the abilities and inability of the pupils in carrying out the tasks given by the researcher. The data processing method in this research was by comparing the pupil learning outcomes before the action with the pupils' learning outcomes after the action.

Table 2. Activity criteria (A) of teacher, pupils and CLA

\begin{tabular}{cc}
\hline Range & Category \\
\hline $\mathrm{A} /$ CLA $\geq 80$ & Excellent (E) \\
\hline $70 \leq \mathrm{A} /$ CLA $<80$ & Good (G) \\
\hline $60 \leq \mathrm{A} /$ CLA $<70$ & Moderate (M) \\
\hline $40 \leq \mathrm{A} /$ CLA $<60$ & Less (L) \\
\hline $40>$ A $/$ CLA & Fail (F) \\
\hline
\end{tabular}

\section{RESULTS}

This CAR has succeeded in increasing the CLA pupils. In addition, the activities of pupils and teachers experienced an increase at the end of the cycle. The increase in impact occurs from the application of the CTL approach. Figures $1-4$ present our CAR findings. 


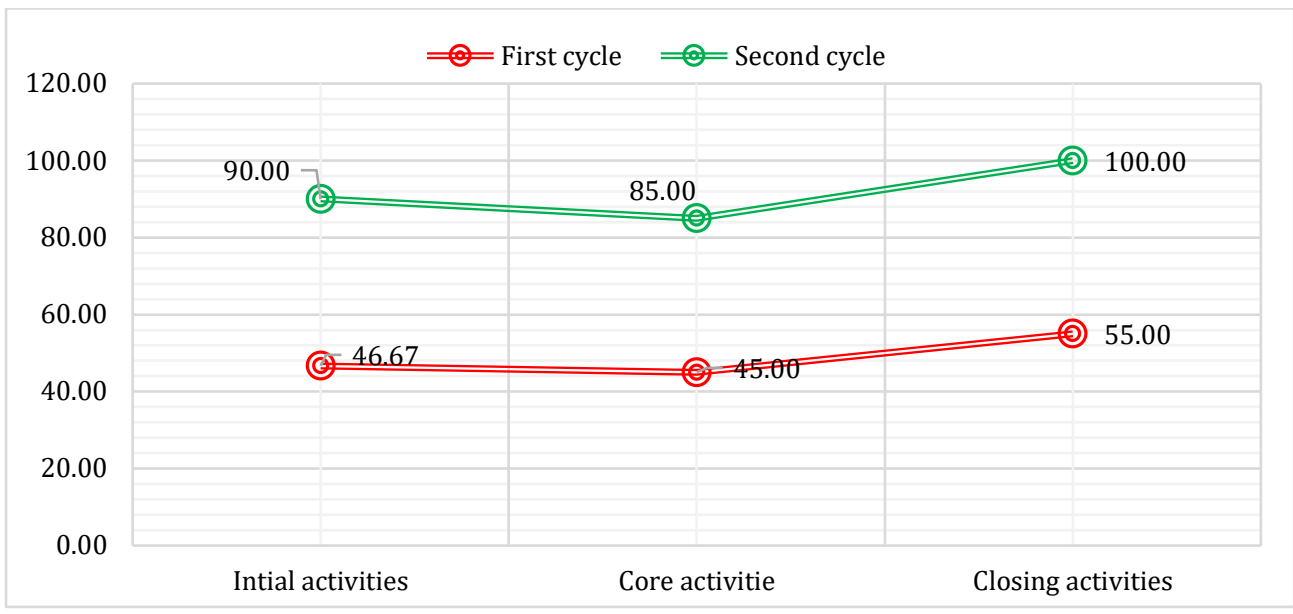

Fig. 1. Teacher activities

Based on the findings of the teacher's activities in Figure 1, it can be seen that the pupils' activities in the first cycle for initial activities, core activities and CLA, and closing activities are still lacking. Improvements were made in the second cycle stage. The second cycle stage has been improved and the results are different from the findings in the first cycle. In the second cycle, it was revealed that the teacher's activities achieved excellent. The findings of the second cycle stage informed that there was an increase in teacher activity for the three activities measured.

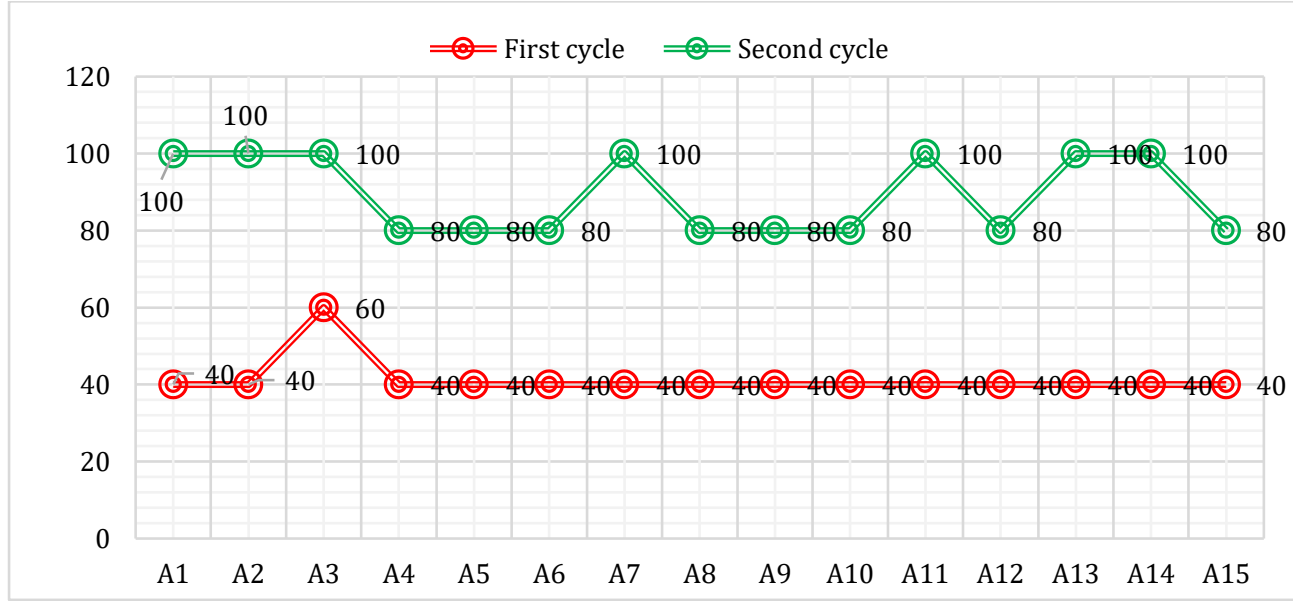

Fig. 2. Pupils activities

The findings of pupil activity in figure 2 indicate that there is an improvement in pupil activity. In the first cycle there was only one, namely A1 (Answering questions correctly and correctly) which rose in the moderate category. The other fourteen activities experienced less achievement. In the second cycle the activities have been improved. All pupil activity in the second cycle stage grew to excellent. This achievement reveals that the CTL approach helps foster pupil activity. 


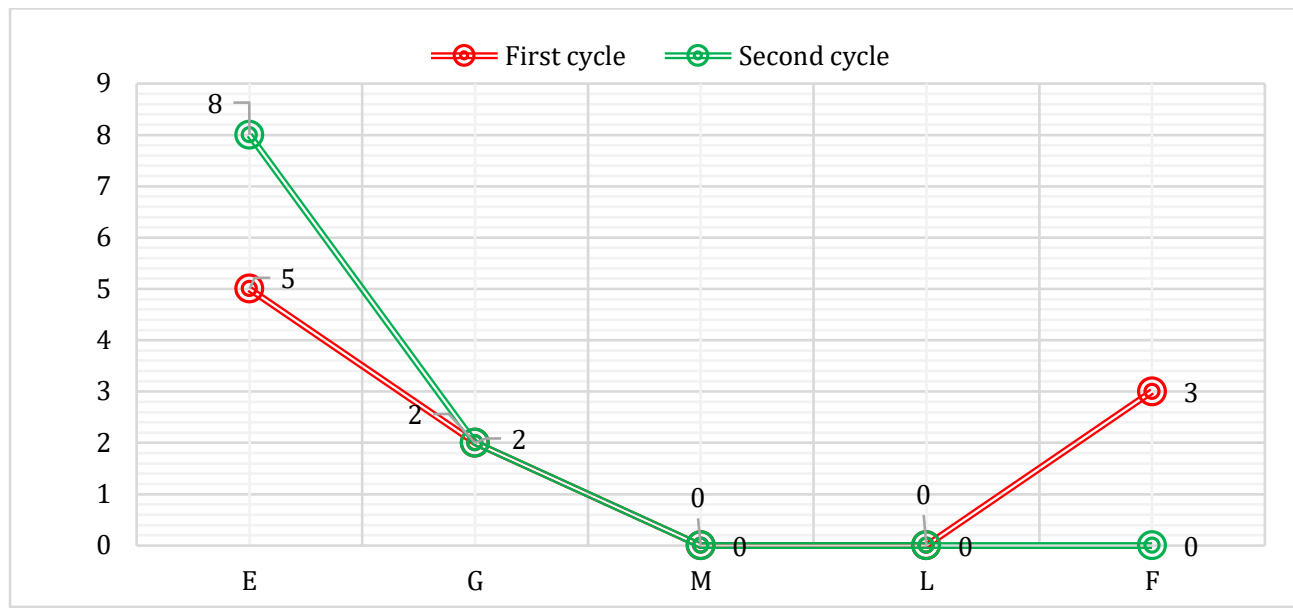

Fig. 3. Pupils CLA categories

The CLA of pupils in figure three displays different data for each cycle. In the first cycle, it was found that five of ten pupils increased in the excellent category. There are two of ten pupils who achieve good results. The other three pupils are failures. Pupil repair was carried out in the second cycle stage. The findings in the second cycle indicated that there were eight pupils (increasing from five to eight) which increased in excellent results. The achievement of good results was experienced by two pupils. In the second cycle, there were no pupils with moderate, less or failed achievements.

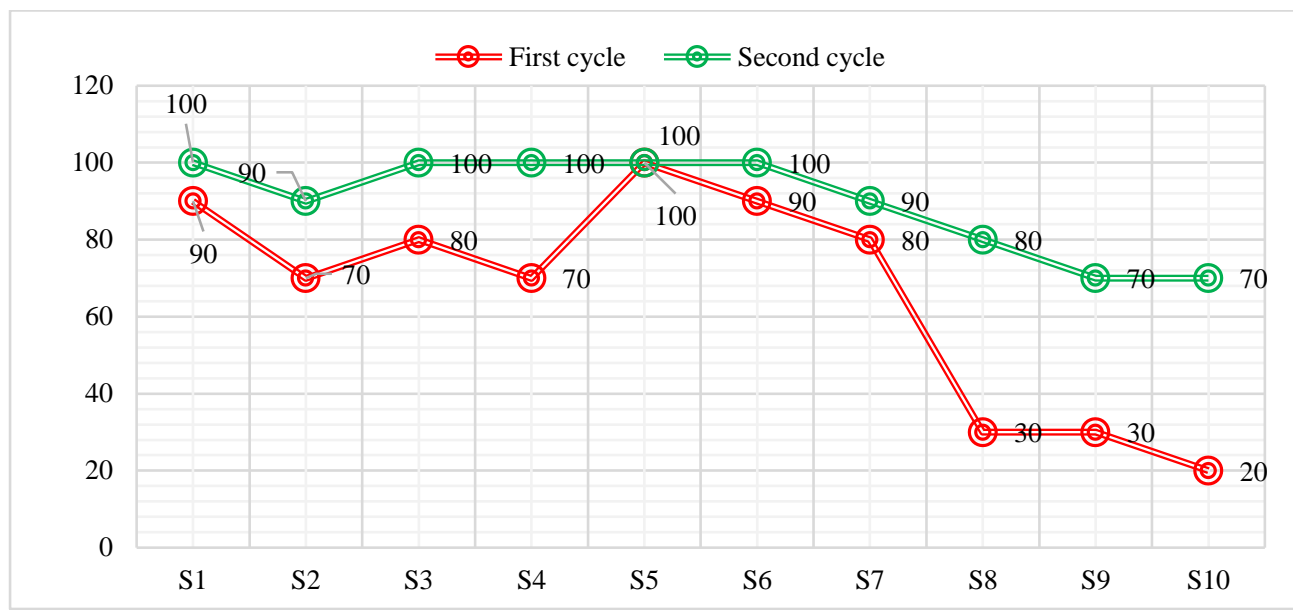

Fig. 4. Pupils CLA

Based on the evaluation results of CLA pupils, we found that $70 \%$ (7 pupils) achieved CCM. There are still 30\% (three pupils) who have not reached CCM in the first cycle. This case shows that the pupils do not understand the learning material well. The teacher must activate the pupils during learning, provide guidance and motivation to the pupils and the teacher must communicate with all pupils, for this reason the researcher reflects as follows:

1. Researchers should be more careful in observing pupil responses when using the CTL Strategy. This is based on the results of the actions that the researcher could not monitor optimally.

2. The teacher must give emphasis to the learning material. 
3. Teachers should motivate pupils to be more active, serious, and enthusiastic in paying attention to teacher explanations.

4. To overcome various weaknesses in the first cycle, it will be improved in the second cycle.

CLA pupils in the second cycle after the learning process was completed obtained an average score of 90 which was better than the second cycle with the percentage of learning pupils in the second cycle was $100 \%$. This shows that the second cycle of pupil learning mastery is better than the first cycle. In the second cycle the researchers did not experience obstacles so that in the second cycle they did not hinder research activities.

Reflection is done to determine whether the second action has been successful or not. In reflecting on the actions of the researcher, he always conducts discussions with subject teachers about various problems that exist in the classroom. With the increase in pupils' learning achievement in the second cycle, it proves that social science learning with communication technology development materials using the Contextual Teaching and Learning (CTL) approach can increase the CLA of grade IV pupils in SDK Doreng. Thus, the implementation of learning only reached the stage of the first and second cycles.

\section{DISCUSSION}

The learning involvement of the fourth grade students of SDK Doreng is very less, when the teacher explains the learning material, the pupils' attention is very low and most of them are silent. At the beginning of observing pupils' learning activities, the researcher saw that the learning process in grade IV still had many shortcomings, in this case; During the learning process, the classroom atmosphere was noisy, pupils were still afraid to ask questions, in completing the evaluation, there were still many pupils whose scores did not reach MCC. One thing that must be considered by teachers is that they must be able to choose various methods and appropriate strategies according to the material to be taught to stimulate pupil activity. The findings revealed that the activities of pupils and teachers both experienced a good increase. These findings were followed by an increase in the CLA pupils. The increase in CLA pupils reached 30\%, where in the first cycle as many as $70 \%$ pupils were complete and $30 \%$ were incomplete. In the second cycle, $100 \%$ of pupils were complete. The findings are related to previous findings. For example, Tohariah, (2021) found that learning social sciences with CTL applications succeeded in increasing pupil completeness with an achievement of $89.29 \%$ at the end of the cycle. Other researchers have also found that CTL can successfully improve CLA pupils (Astari \& Witri, 2015; Jati, 2020; Juliana et al., 2019).

Our research has found that the use of CTL has a positive impact on students. CTL provides an immersive experience for pupils. Pupils become active during teaching and learning. CTL approaches play an important role in achieving the required learning goals (Putri \& Yohandri, 2020). CTL makes pupil activity well developed. Pupils can actively ask, discuss, answer questions, provide solutions, and can connect between concepts. In this research, for example, pupils are able to answer questions (A2) and defend arguments (A4). In CTL the pupils are able to answer questions and 93.34\% pupils are complete (Sulfemi, 2019). Pupils is able to speak well. CTL has an effect on pupils' speaking ability (Suadiyatno et al., 2020). Pupil abilities are honed well with the use of CTL. Pupils' activities in learning 
are varied. Many pupil activities are fostered in the CTL implementation. Pupil activity reached Excellent when applying CTL (Purwati et al., 2019).

In CTL, pupils learn to relate one thing to another. It can be seen from the activity of A13 which is able to connect between concepts. When pupils are able to relate concepts, they think they become better. They know not only one concept, but many concepts. The number of concepts they know is followed by their ability to relate one concept to another. Pupils can understand concepts and can relate them because they learn concepts that come from the real world. CTL is a full instructional method that helps pupils to understand the learning material through the relation between their real-life problems and their theory (Hakim et al., 2020). This theory is supported by the real activity of the pupils, namely in A8 (providing concrete examples) and A8 (connecting with reality).

Pupils' activities in learning have changed for the better because of the encouragement from the teacher. It can be seen that in figure 1 the teacher's activity improved in the second cycle. It was quoted by the activity of his pupils. This fact is in contradiction with previous research which found that there was less stimulation from the teacher for pupils to ask questions, so that in CTL pupils there were fewer questions (Anggraeni et al., 2017). To empower pupil activity, teacher activity must be increased. In this research, the use of CTL actually helps pupils to ask questions. Even pupils can think well. Pupils will develop their thinking by working together and increasing their knowledge (Hakim et al., 2020). Use of CTL in Action research fulfills this activity. Pupils' knowledge of social science material concepts increases. CTL contributes to the development of CLA (Saryati \& Yulia, 2019). The action research that we have done has successfully implemented CTL. The activities of teachers and pupils as well as CLA pupils are excellent. In the implemented CTL, pupils work together. Their cooperation takes place in the investigative group. They investigate real world problems. CTL helps pupils to work in teams, problem solving, involvement in learning, and their spirit (Rodiah, 2020). Research recommends future use of CTL. CTL contributes both to activity improvement and to CLA pupils. CTL can build pupils' knowledge. Their knowledge is built as a result of activities during the learning process. Good activity followed by good CLA.

\section{CONCLUSION}

Based on the results of the class action research conducted at SDK Doreng, it can be concluded that the implementation of the contextual teaching and learning can enhance the cognitive learning achievement of pupils in grade IV SDK Doreng. The improvement in learning outcomes is shown by the Cycle I results to Cycle II study, i.e., the average value of pupils learning outcomes increased from $70 \%$ to $100 \%$.

\section{REFERENCES}

Abdullah. (2017). Pendekatan dan model pembelajaran yang mengaktifkan siswa. Edureligia, 1(1), 45-62.

Anggraeni, T., Sugiyo, \& Kustiono. (2017). The Difference of ability to ask, scientific attitude, motivation before and after following contextual teaching and learning model. Journal of Primary Education, 6(3), 248-256.

Astari, E., \& Witri, G. (2015). Penerapan model contextual teaching and learning (CTL) untuk meningkatkan hasil belajar matematika siswa kelas IV SD Negeri 105 Pekanbaru. Jurnal Online Mahasiswa Fakultas Keguruan Dan Ilmu Pendidikan Universitas Riau, 2(2), 
$1-9$.

Astuti, J., Novita, M., \& Ismalil, M. S. (2020). Peningkatan motivasi belajar menggunakan contextual teaching and learning di Madrasah Ibtidaiyah Swasta Raudhatul Mujawwidin Tebo. JURNAL EDUCATIVE: Journal of Educational Studies, 5(1), 16-28.

Firdaus, \& Dewi, F. (2018). Application of contextual teaching and learning (CTL) components in telecommunication network design and optimization course. International Journal of Chemistry Education Research, 2(1), 24-33.

Hakim, R., Ritonga, M., \& Susanti, W. (2020). Implementation of Contextual teaching and learning in Islamic Education at Madrasah Diniyah. Jour of Adv Research in Dynamical \& Conrol Systems, 3326-3332. https://doi.org/10.5373/JARDCS/V12I2/S20201455

Hyun, C. C., Wijayanti, L. M., Asbari, M., Purwanto, A., Santoso, P. B., Igak, W., Bernarto, I., \& Pramono, R. (2020). Implementation of contextual teaching and learning (CTL) to improve the concept and practice of love for faith-learning integration. International Journal of Control and Automation, 13(1), 365-383.

Jati, D. H. P. (2020). Peningkatan hasil belajar PPKn melalui pembelajaran online berbasis QUIZIZZ. Jurnal Mitra Pendidikan, 4(1), 1-9. http://www.ejurnalmitrapendidikan.com/index.php/e-jmp/article/view/737/473

Juliana, J., Marli, S., \& Sabri, T. (2019). Peningkatan Hasil Belajar IPS Menggunakan Contextual Teaching and Learning Siswa Sekolah Dasar. Jurnal Pendidikan Dan $\begin{array}{rrr}\text { Pembelajaran } \quad \text { Khatulistiwa, } & 8(1), & 1-8 .\end{array}$ http://jurnal.untan.ac.id/index.php/jpdpb/article/view/30665

Kemmis, S., \& McTaggart, R. (1988). The Action research planner (3rd ed.). Deakin University Press.

Nusantari, E., Utina, R., Katili, A. S., Tamu, Y., \& Damopolii, I. (2020). Effectiveness of environmentally-based science learning towards environmentally-friendly character of students in coastal area. International Journal of Instruction, 13(3), 233-246.

Prastuti, A. E., Sarmini, \& Purnomo, N. H. (2020). Implementation of Contextual Teaching and Learning Social Sciences Subjects to Increase Motivation and Learning Achievement. The Indonesian Journal of Social Studies, 3(2), 67-73.

Purwati, P., Marasabessy, F., \& Damopolii, I. (2019). Enhancing students activity and problem solving skill through CTL-based local wisdom approach. Journal of Physics: Conference Series, 1321(3), 032077. https://doi.org/10.1088/1742$6596 / 1321 / 3 / 032077$

Putri, Y. A., \& Yohandri. (2020). Validity of Teaching Materials Based on Problem Based Learning Using Contextual Teaching and Learning Approach to Improve Critical Thinking. 769 International Journal of Progressive Sciences and Technologies (IJPSAT), 23(1), 63-70.

Rodiah. (2020). Implementation of contextual teaching and learning model (CTL) to improve students' learning motivation in grade 3 SDN Wanoja 01. Social, Humanities, and Education Studies (SHEs): Conference Series, 3(3), 48-56.

Sarwinda, K., Rohaeti, E., \& Fatharani, M. (2020). The development of audio-visual media with contextual teaching learning approach to improve learning motivation and critical thinking skills. Psychology, Evaluation, and Technology in Educational Research, 2(2), 98. https://doi.org/10.33292/petier.v2i2.12

Saryati, T., \& Yulia, Y. (2019). Contextual teaching and learning approach to supplementary reading materials based on 2013 Curriculum. Journal of English Language and Pedagogy, 2(1), 1. https://doi.org/10.36597/jelp.v2i1.3703

Suadiyatno, T., Firman, E., Hanan, A., \& Sumarsono, D. (2020). Examining the effect of contextual teaching-learning and anxiety towards students' speaking skills. Journal of $\begin{array}{llll}\text { Languages and Language } & \text { 8(1), }\end{array}$ https://doi.org/10.33394/jollt.v8i1.2266 
Sulfemi, W. B. (2019). Model pembelajaran contextual teaching and learning (CTL) Berbantu media miniatur lingkungan untuk meningkatkan hasil belajar IPS. Edunomic Jurnal Pendidikan Ekonomi, 7(2), 73. https://doi.org/10.33603/ejpe.v7i2.1970

Susiloningsih, W. (2016). Model Pembelajaran CTL (Contextual Teaching and Learning) dalam meningkatkan hasil belajar mahasiswa pgsd pada matakuliah konsep IPS dasar. PEDAGOGIA: Jurnal Pendidikan, 5(1), 57. https://doi.org/10.21070/pedagogia.v5i1.89

Tohariah, T. (2021). Penerapan model contextual teaching and learning (CTL) untuk meningkatkan pemahaman mata pelajaran IPS. J-KIP (Jurnal Keguruan Dan Ilmu Pendidikan), 2(1), 79-84.

Tutut Rahmawati. (2018). Penerapan model pembelajaran CTL untuk meningkatkan hasil belajar siswa sekolah dasar pada mata pelajaran IPA. Jurnal Ilmiah Pendidikan Dan Pembelajaran, 2(1), 12-20.

Utami, Y. W. (2021). Penggunaan metode contextual teaching and learning (CTL) untuk meningkatkan pretasi belajar siswa pada mata pelajaran IPS kelas VII di SMP Negeri 2 Dringu Kabupaten Probolinggo. Pedagogy, 8(1), 60-65.

Widodo, U. (2020). Contextual teaching and learning: an alternative method to teach speaking. SELL Journal: Scope of English Language Teaching, Linguistics, and Literature, 5(2), 115-130. $\quad$ http://www.publikasi.stkippgribkl.ac.id/index.php/SL/article/download/424/343 